\title{
極超音速圧縮コーナ流れの境界層再付着とキャビティの干渉による空力加熱林
}

\section{Aerodynamic Heating Due to Interaction between Boundary Layer Reattachment and Rectangular Cavity in Hypersonic Compression Ramp}

\author{
横 井 宏 尚*2・小 澤 啓 伺*2・松 本 宗一郎*2・土 井 克 則*2・中 村 佳 朗*2 \\ Hironao Yokoi, Hiroshi Ozawa, Soichiro Matsumoto, Katsunori Doi and Yoshiaki NaKamura
}

Key Words : Hypersonic Compression Ramp, Boundary Layer Reattachment, Heat Transfer Rate, Hypersonic Cavity Flow

\begin{abstract}
The interaction between laminar boundary layer reattachment and a rectangular cavity in a hypersonic compression ramp was investigated numerically and experimentally. It was found from the present results that the separation bubble becomes larger than that of the baseline flat ramp case. This is caused by higher adverse pressure gradient due to the cavity end wall. In the flowfield a high temperature separated shear layer collides with the endwall of cavity, where a hot stagnation point is formed. The endwall heat flux becomes about 10 times as large as the maximum heat flux in the baseline flat ramp case.
\end{abstract}

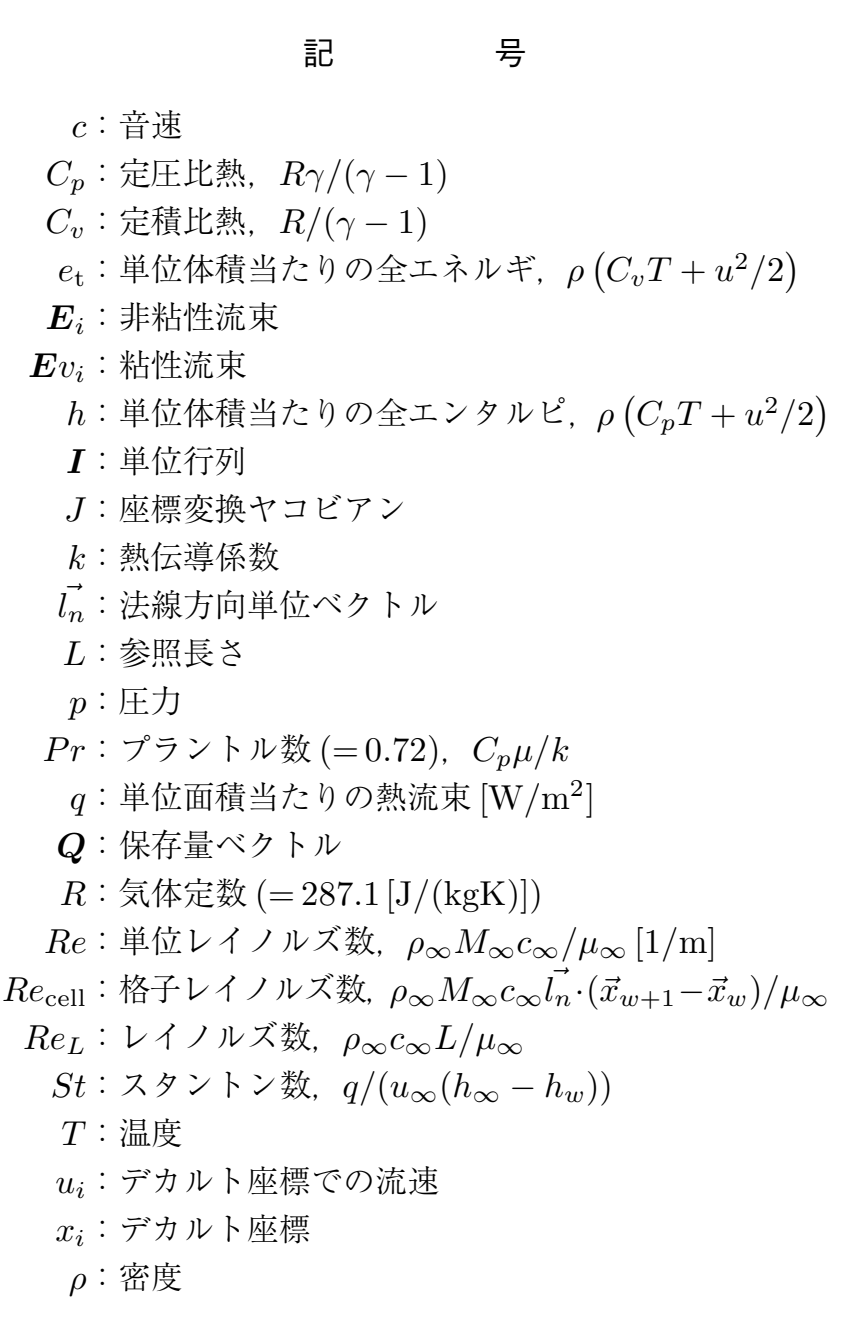

*1 (C) 2011 日本航空宇宙学会

平成 22 年 9 月 9 日原稿受付

*2 名古屋大学大学院工学研究科航空宇宙工学専攻

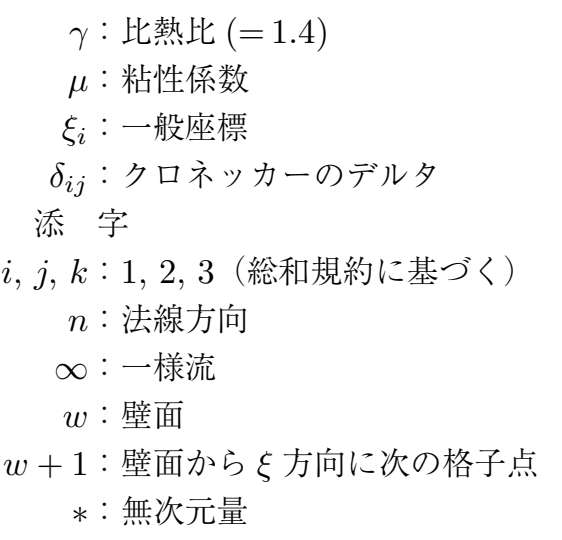

1. は じめ に

2003 年スペースシャトルコロンビア号の空中分解事故は, 大気圈再突入後の極超音速下で, 左翼前縁の断熱夕イルの 剝離部から空力加熱により発生した熱が機体に浸入し，そ の結果, アルミ構造部材を溶解し, 空気力に耐えかねた機 体は左翼から空中分解に至ったと報告されている1).

この事故を受けて，断熱夕イル剝離を模擬した極超音速 下の矩形キャビティ流れの研究が盛んに行われている ${ }^{2 \sim 4)}$. それらの多くは矩形キャビティの前縁壁エッジから発生す る剪断層とキャビティの後縁壁との干渉により壁面熱流束 が増加するとの報告である。

本研究では，極超音速中の圧縮コーナ流れ5)（第 1 困）に 存在する剥離泡の境界層再付着点直後のネック領域に注目 した。ネック領域（第 2 図）では，境界層厚さが圧縮性の 影響により最小となり, 大量の剪断発熱を伴い, 壁面熱流 束が最大となる。このように高温高密度下にある再付着点 近傍に，外乱要因として矩形キャビティを設けた場合の壁 面熱流束への影響について調べる. 


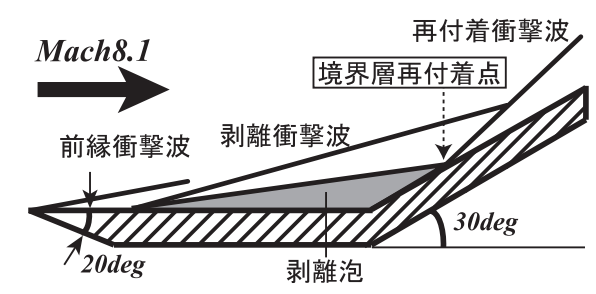

第 1 図 極超音速中の圧縮コーナ流れの模式図

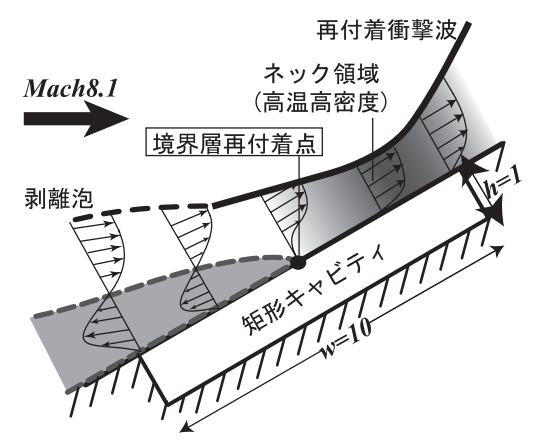

第 2 図境界層再付着点近傍とキャビティの位置関係

\section{2. 計 算 方 法}

\section{1 支配方程式}

a）支配方程式：一般化座標での 3 次元圧縮性ナビエ・又 トークス方程式（第 1 表参照）

$$
\begin{aligned}
& \frac{\partial \hat{\boldsymbol{Q}}}{\partial t^{*}}+\frac{\partial \hat{\boldsymbol{E}}_{i}}{\partial \xi_{i}}+\frac{1}{R e_{L}} \frac{\partial \hat{\boldsymbol{E}} v_{i}}{\partial \xi_{i}}=0 \\
& \hat{\boldsymbol{E}}_{i} \equiv \frac{1}{J} \frac{\partial \xi_{i}}{\partial x_{j}^{*}} \boldsymbol{E}_{j}^{*}, \quad \hat{\boldsymbol{E}} v_{i} \equiv \frac{1}{J} \frac{\partial \xi_{i}}{\partial x_{j}^{*}} \boldsymbol{E} v_{j}^{*}, \quad \hat{\boldsymbol{Q}} \equiv \frac{1}{J} \boldsymbol{Q}^{*} \\
& \boldsymbol{Q}^{*}=\left(\begin{array}{c}
\rho^{*} \\
\rho^{*} u_{i}^{*} \\
e_{\mathrm{t}}^{*}
\end{array}\right), \quad \boldsymbol{E}_{i}^{*}=\left(\begin{array}{c}
\rho u_{i}^{*} \\
\rho u_{i}^{*} u_{j}^{*}+p^{*} \delta_{i j} \\
\left(e_{\mathrm{t}}^{*}+p^{*}\right) u_{i}^{*}
\end{array}\right) \\
& \boldsymbol{E} v_{i}^{*}=\left(\begin{array}{c}
0 \\
\boldsymbol{\tau}_{i j}^{*} \\
\boldsymbol{\tau}_{i j}^{*} u_{j}^{*}-k^{*} \frac{\partial T^{*}}{\partial x_{i}^{*}}
\end{array}\right)
\end{aligned}
$$

応力テンソル, 熱伝導倸数, 及び状態方程式は以下の式で 与えられる。作動流体は空気で, 完全気体とする.

$$
\begin{gathered}
\tau_{i j}^{*}=-\mu^{*}\left(\frac{\partial u_{i}^{*}}{\partial x_{j}^{*}}+\frac{\partial u_{j}^{*}}{\partial x_{i}^{*}}\right)+\lambda\left(\frac{\partial u_{k}^{*}}{\partial x_{k}^{*}} \delta_{i j}\right) \\
k^{*}=\frac{C_{p}^{*} \mu^{*}}{P r}, \quad p^{*}=\rho^{*} R^{*} T^{*}
\end{gathered}
$$

ただし，ストークス仮説より $\lambda=2 / 3 \mu^{*}$ とする.

サザランド式 ${ }^{6)}$ より任意の静温 $T[\mathrm{~K}]$ での粘性係数 $\mu[\mathrm{Pa} \cdot \mathrm{s}]$ は, サザランド定数 $S_{1}$ と $S_{2}$ と共に以下の式 で与えられる。

$$
\begin{aligned}
& \mu(T)=\frac{S_{1} T^{3 / 2}}{T+S_{2}} \\
& S_{1}=1.458 \times 10^{-6}\left[\mathrm{~kg} /\left(\mathrm{m} \cdot \mathrm{s} \cdot \mathrm{K}^{1 / 2}\right)\right] \\
& S_{2}=110.4[\mathrm{~K}]
\end{aligned}
$$

\begin{tabular}{ll} 
& 第 1 表 諸量の無次元化 \\
\hline 座標 & $x_{i}^{*} \equiv x_{i} / L$ \\
時間 & $t^{*} \equiv \frac{t}{L / c_{\infty}}$ \\
流速 & $u_{i}^{*} \equiv u_{i} / c_{\infty}$ \\
粘性係数 & $\mu^{*} \equiv \frac{\mu}{\mu_{\infty}}=\left(\frac{T}{T_{\infty}}\right)^{\frac{3}{2}}\left(\frac{T_{\infty}+S_{2}}{T+S_{2}}\right)$ \\
$\quad$ 式 $(2)$ & $\rho^{*} \equiv \rho / \rho_{\infty}$ \\
密度 & $p^{*} \equiv \frac{p}{\rho_{\infty} c_{\infty}^{2}}$ \\
圧力 & $T^{*} \equiv T / T_{\infty}$ \\
温度 & $R^{*} \equiv \frac{R}{c_{\infty}^{2} / T_{\infty}}$ \\
気体定数 & \\
熱伝導係数 & $k^{*} \equiv \frac{\mu^{*} \gamma R^{*}}{\operatorname{Pr}(\gamma-1)}=\frac{k}{\gamma \mu_{\infty} R}$ \\
\hline
\end{tabular}

b) 離散化法：セル節点有限体積法.

c) 高次精度化 : 3 次精度 MUSCL 法（Van Albada 制限 関数を用い TVD 条件を満足).

d) 非粘性流束：SHUS ${ }^{7}$.

e) 粘性流束：二次精度中心差分（乱流モデルなし）。

f) 時間積分法：LU-SGS ${ }^{8,9)}$. 式 (1) を, オイラー陰解法 により離散化し, $n+1$ ステップの非粘性流束と粘性流束 を $n$ ステップまわりにテイラー展開する（式 (3)).

$$
\left(\frac{1}{\Delta t^{*}}+\frac{\partial \hat{A}_{i}^{n}}{\partial \xi_{i}}\right) \Delta \hat{\boldsymbol{Q}}=-\frac{\partial}{\partial \xi_{i}}\left(\hat{\boldsymbol{E}}_{i}+\frac{\hat{\boldsymbol{E}} v_{i}}{R e_{L}}\right)^{n}
$$

ただし

$$
\hat{A}_{i}^{n} \equiv\left(\frac{\partial \hat{\boldsymbol{E}}_{i}}{\partial \hat{\boldsymbol{Q}}}+\frac{1}{R e_{L}} \frac{\partial \hat{\boldsymbol{E}} v_{i}}{\partial \hat{\boldsymbol{Q}}}\right)^{n}
$$

式 (3) に対する LU-SGS 法を式 (4) と式 (5) に示す.

$$
\begin{aligned}
& \text { forward sweep }\left.\Delta \hat{\boldsymbol{Q}}^{\text {new }}\right|_{i, j, k} \\
& =\left.\left(\frac{1}{\Delta t}+\frac{\tilde{\rho}\left(\hat{A}_{i}\right)}{\Delta \xi_{i}}\right)^{-1}\right|^{-\partial\left(\hat{\boldsymbol{E}}_{i}+\frac{\hat{\boldsymbol{E}} v_{i}}{R e_{L}}\right)^{n}} \\
& +\left.\left(\frac{\hat{A}_{1}^{+} \Delta \hat{\boldsymbol{Q}}^{\mathrm{new}^{\prime}}}{\Delta \xi_{1}}\right)\right|_{i-1, j, k}+\left.\left(\frac{\hat{A}_{2}^{+} \Delta \hat{\boldsymbol{Q}}^{\mathrm{new}^{\prime}}}{\Delta \xi_{2}}\right)\right|_{i, j-1, k} \\
& \left.+\left.\left(\frac{\hat{A}_{3}^{+} \Delta \hat{\boldsymbol{Q}}^{\text {new }}}{\Delta \xi_{3}}\right)\right|_{i, j, k-1}\right) \\
& \text { backward sweep }\left.\Delta \hat{\boldsymbol{Q}}^{\text {new }}\right|_{i, j, k} \\
& =\left.\Delta \hat{\boldsymbol{Q}}^{\text {new }}\right|_{i, j, k}-\left(\frac{1}{\Delta t}+\frac{\tilde{\rho}\left(\hat{A}_{i}\right)}{\Delta \xi_{i}}\right)^{-1} \\
& \quad \times\left(\left.\left(\frac{\hat{A}_{1}^{-} \Delta \hat{\boldsymbol{Q}}^{\text {new }}}{\Delta \xi_{1}}\right)\right|_{i+1, j, k}+\left.\left(\frac{\hat{A}_{2}^{-} \Delta \hat{\boldsymbol{Q}}^{\text {new }}}{\Delta \xi_{2}}\right)\right|_{i, j+1, k}\right. \\
& \left.\quad+\left.\left(\frac{\hat{A}_{3}^{-} \Delta \hat{\boldsymbol{Q}}^{\text {new }}}{\Delta \xi_{3}}\right)\right|_{i, j, k+1}\right)
\end{aligned}
$$


ただし，

$$
\left\{\begin{array}{l}
\hat{A}_{i}^{ \pm} \approx \frac{\hat{A}_{i} \pm \tilde{\rho}\left(\hat{A}_{i}\right) \boldsymbol{I}}{2} \\
\tilde{\rho}\left(\hat{A}_{i}\right)=\frac{\partial \xi_{i}}{\partial x_{j}^{*}} u_{j}^{*}+\sqrt{\sum_{j}\left(\frac{\partial \xi_{i}}{\partial x_{j}^{*}}\right)^{2}}\left(c^{*}+\frac{2 \mu^{*}}{R e_{L} \rho^{*} \Delta \xi_{i}}\right)
\end{array}\right.
$$

$$
\hat{A}_{i}^{ \pm} \Delta \hat{\boldsymbol{Q}} \approx 0.5(\hat{\boldsymbol{E}}(Q+\Delta Q)-\hat{\boldsymbol{E}}(Q) \pm \tilde{\rho}(\tilde{A}) \Delta \hat{\boldsymbol{Q}})
$$

g）無次元化：一様流の物理量で無次元化を行った（第 1 表).

h) 並列化 : MPICH1 (128 CPU コア並列計算)

2.2 壁面熱流束の計算方法 壁面熱流束を式(8)のフー リエの法則により見積もった。

$$
\begin{aligned}
q & =\left.k \frac{\mathrm{d} T}{\mathrm{~d} x_{n}}\right|_{i+\frac{1}{2}, w} \\
& =\frac{C_{p}}{\operatorname{Pr}} \frac{S_{1} T_{i+\frac{1}{2}, w+1}^{3 / 2}}{T_{i+\frac{1}{2}, w+1}+S_{2}} \frac{\left(T_{i+\frac{1}{2}, w+1}-300[\mathrm{~K}]\right)}{\left(\vec{x}_{i+\frac{1}{2}, w+1}-\vec{x}_{i+\frac{1}{2}, w}\right) \cdot \overrightarrow{l_{n}}}
\end{aligned}
$$

$R e_{\text {cell }}$ は, 壁面熱流束值に大きな影響を与えるため, キャ ビティなし圧縮コーナ流れ場の壁面熱流束の格子収束性に ついて調査した。 その結果, $R e_{\text {cell }} \fallingdotseq 100$ 以内であれば壁 面熱流束值が格子間隔に依存せず一定となった。本研究で は, $R e_{\text {cell }}=30.8$ とした $\left(\mathrm{d} x_{n}=5[\mu \mathrm{m}]\right.$ (第 3 表 $\left.)\right)$.

\section{3. 計 算 条 件}

名古屋大学衝撃風洞（第 2 表）テストセクションの流れ を計算の一様流条件（第 3 表）とした。総温は, 衝撃波の

\begin{tabular}{|c|c|c|c|}
\hline & & キャビテイなし & キャビティあり \\
\hline \multirow[t]{2}{*}{ 格子 } & & \multirow{2}{*}{\multicolumn{2}{|c|}{$\begin{array}{c}320 \times 109 \times 514 \quad 360 \\
5[\mu \mathrm{m}]\end{array}$}} \\
\hline & 最小格子（壁面 & & \\
\hline 境界 & $\begin{array}{l}\text { (1)流入部 } \\
\text { (2)流出部 } \\
\text { (3)固体壁面 } \\
\text { (4)底面 } \\
\text { (5)左右側面 } \\
\text { 上面 }\end{array}$ & \multicolumn{2}{|c|}{$\begin{array}{c}\zeta \text { 方向 } 0 \text { 次外挿 } \\
\text { ノンスリップ, 等温壁 }\left(T_{w}=300[\mathrm{~K}]\right) \\
\xi \text { 方向 } 0 \text { 次外挿 } \\
\text { 一様流条件 } \\
\text { 一様流条件 }\end{array}$} \\
\hline \multicolumn{2}{|c|}{ 初期条件 } & インパルシブスタート & 2 次元収束解 \\
\hline \multicolumn{2}{|c|}{$\begin{array}{l}\mathrm{CFL} \\
\text { 時間刻み } \Delta t \\
\text { 合計時間 } \Sigma \Delta t\end{array}$} & $\begin{array}{c}\text { 約 } 1.5 \\
\text { 約 } 2.3[\mathrm{nsec}] \\
\text { 約 } 20[\mathrm{msec}]\end{array}$ & $\begin{array}{c}\text { 約 } 0.2 \\
\text { 約 } 0.3[\mathrm{nsec}] \\
\text { 約 } 0.91[\mathrm{msec}]\end{array}$ \\
\hline
\end{tabular}
一次元理論 ${ }^{10)}$ 及び, 衝撃風洞の直接数值計算 ${ }^{11)}$ を参考に

\begin{tabular}{ll}
\multicolumn{1}{c}{ 第 2 表 } & 一様流条件 : 名古屋大学衝撃風洞 \\
\hline 総圧 & $P_{0}=4.0[\mathrm{MPa}]$ \\
総温 & $T_{0}=900[\mathrm{~K}]$ \\
マッハ数 & $M_{\infty}=8.1$ \\
単位レイノルズ数 & $R e=6.185 \times 10^{6}[1 / \mathrm{m}]$ \\
\hline
\end{tabular}

第 3 表 計算条件
して決定した.

第 3 図に一様流に対し迎角 0 の水平板（流れ方向： $130[\mathrm{~mm}]$, スパン方向 : $100[\mathrm{~mm}])$ と斜板 $(30[\mathrm{deg}])$ か らなるキャビティなし圧縮コーナの計算モデルを示す。第 4 図にキャビティあり圧縮コーナの計算モデルを示す。矩 形キャビティ（幅 $w=10[\mathrm{~mm}]$, 高さ $h=1[\mathrm{~mm}] ）$ は, キャビティなしの境界層再付着点を中心に設置し(第 2 図), $L 0=158[\mathrm{~mm}]$ とした

3.1 計算格子 第 5 図にキャビティなしの構造格子と, 座標系（右手系直交座標系と一般座標系）を示す，格子点 数は, キャビティなしの場合には, $17,928,320$ 点, キャビ ティありの場合には, $30,738,960$ 点である (第 3 表).

3.2 境界条件 平板前縁から $5[\mathrm{~mm}]$ と, 平板両側から 10〜 $15[\mathrm{~mm}]$ 距離（第 5 図中の(4)）をおき，一様流条件と している。キャビティは，ブランク格子とすることで再現

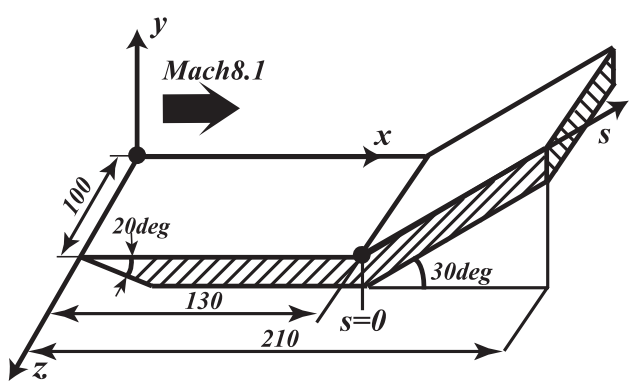

第3図 キャビティなし圧縮コーナ

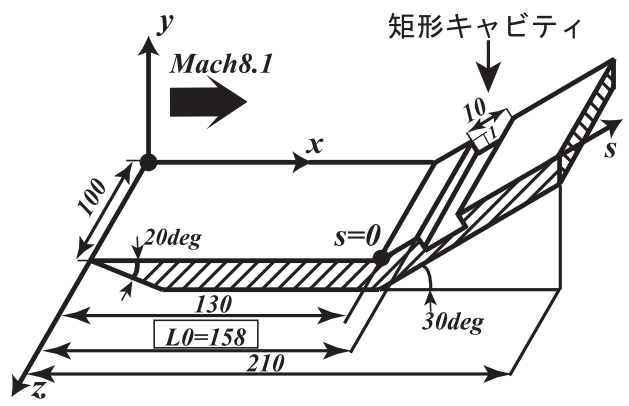

第 4 図 キャビティあり圧縮コーナ

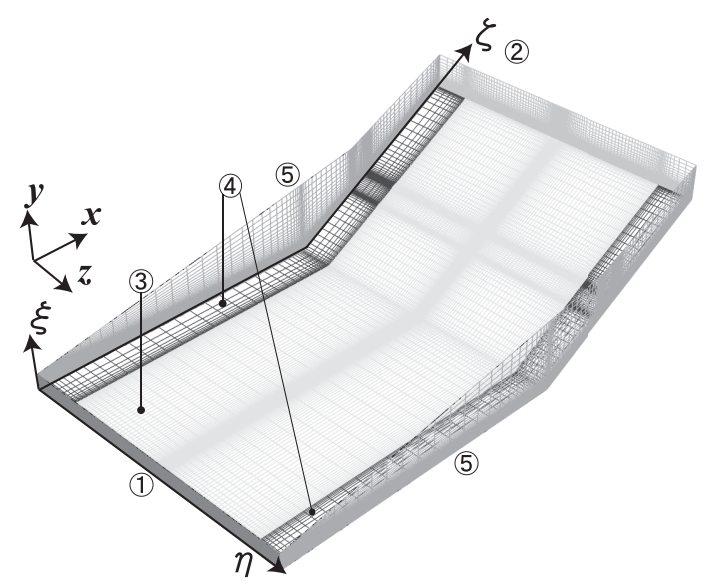

第 5 図 構造格子と座標系 
した，その他の境界条件の詳細は第 3 表と第 5 図に示した.

3.3 初期条件 キャビティなし計算では, 計算全域を一 様流とするインパルシブスタートとした。キャビティあり 計算は，2 次元計算の収束解を初期条件とした。

3.4 計算環境 スーパーコンピュー夕（Fujitsu HX600） で $128 \mathrm{CPU} コ ア の$ 並列計算を行った. CPU 境界は $\zeta$ 方向 に等格子点数間隔にある。計算時間は 4 週間程度である.

\section{4. 実 験 方 法}

実験条件は, 計算条件と同じなので 3 章を参照されたい. キャビティ位置は, キャビティなしの境界層再付着点を中 心に設置し（第 2 図）， $L 0=143[\mathrm{~mm}]$ (第 4 図）とした. キャビティの位置の考察は 5.2 節を参照されたい.

4.1 壁面熱流束の計測方法 $1.9 \mathrm{~mm}$ 同軸熱電対 (MULLER 社製 Coaxial Thermocouple MCT/MCTB) により温度の時間変化を計測した後, 式 $(9)^{12)}$ から壁面熱 流束を見積もった。ここで, $\sqrt{\rho c k}$ は熱電対の物性值であ る. 壁面熱流束は, 総圧が 3.9 [MPa] となる時刻を中心に 約 10 [msec] 区間での值を平均化した。この区間では, 一 様流中に水平に設置した直径が $23[\mathrm{~mm}]$ の半球円柱の澱み 点の熱流束が一定となり, 総温が一定となることを確認し ている.

$$
q\left(t_{m}\right)=2 \sqrt{\frac{\rho c k}{\pi}} \sum_{i=1}^{m} \frac{T\left(t_{i}\right)-T\left(t_{i-1}\right)}{\sqrt{t_{m}-t_{i}}+\sqrt{t_{m}-t_{i-1}}}
$$

\section{5. 結 果と考 察}

5.1 キャビティなしの場合 計算結果として, 第 8 図 の密度の空間微分の分布と, 第 9 図にシュリーレン写真を 示す。境界層の排除効果に伴う前縁衝撃波, 圧縮コーナ斜 板による逆圧力勾配に伴い発生する境界層剝離と剝離衝撃 波, 及び境界層再付着点からの再付着衝撃波は, 計算と実 験で定性的に一致している。一方で, 計算結果は実験結果 より剝離泡が若干大きくなり, 再付着点位置が $s$ 方向（第 3 図）に約 $17.3[\mathrm{~mm}]$ 下流にずれた。

第 10 図に壁面熱流束の結果を示す。計算結果 $\langle S t\rangle$ は一 様流の影響を受ける両端を除いて, スパン方向 $\left(\left(z_{1}=5\right)\right.$ $\left.<z[\mathrm{~mm}]<\left(z_{2}=95\right)\right)$ の断面平均值を, 流れ場が定常 状態になった区間の時間平均 $(t=2 \sim 20[\mathrm{msec}])$ した結 果を示す. 境界層再付着点直後のピーク值(1)は, $\langle S t\rangle=$ $0.0180\left(28.5\left[\mathrm{~W} / \mathrm{cm}^{2}\right]\right)$ で, 誤差範囲として標準偏差 $\pm \sigma$ を示す.また第 6 図に代表断面として $z=75[\mathrm{~mm}]$ 断面の ピーク值(1)の確率密度の分布を示す。ピーク值(1)はほぼ正 規分布に従って值がばらついており, 流れ場が定常状態に なってからの十分なサンプル区間をとった統計量（第 4 表） で議論していることを示す.なお $z=75[\mathrm{~mm}]$ 以外の断面 のピーク值 $S t$ の確率密度の分布も同様にほぼ正規分布と なった，実験值のピーク值は， $S t=0.021\left(32.9\left[\mathrm{~W} / \mathrm{cm}^{2}\right]\right)$ であり，計算結果の中には，この実験結果と完全に一致す る時空間のポイントは存在するが, 統計量 $\langle S t\rangle$ では, 1 割 強のずれが生じた。以上からある程度正確に壁面熱流束の
第 4 表 $z$ 方向断面平均熱流束のピーク值の統計量

\begin{tabular}{|c|c|c|c|c|}
\hline \multirow[b]{2}{*}{ 位置 } & \multirow{2}{*}{$\begin{array}{c}\text { キャビティなし } \\
\text { 第 } 10 \text { 図(1) } \\
\end{array}$} & \multicolumn{3}{|c|}{ キャビティあり } \\
\hline & & 第 13 図(2) & 第 13 図(3) & 第 13 図(4) \\
\hline デー夕区間 & $2 \sim 20[\mathrm{msec}]$ & \multicolumn{3}{|c|}{$0.3 \sim 0.91[\mathrm{msec}]$} \\
\hline 時間平均 $\langle S t\rangle$ & 0.0180 & 0.177 & 0.10 & 0.048 \\
\hline 最大値 & 0.0189 & 0.42 & 0.17 & 0.06 \\
\hline 最小値 & 0.0166 & 0.10 & 0.07 & 0.04 \\
\hline 標準偏差 $\sigma$ & 0.0005 & 0.033 & 0.01 & 0.006 \\
\hline
\end{tabular}
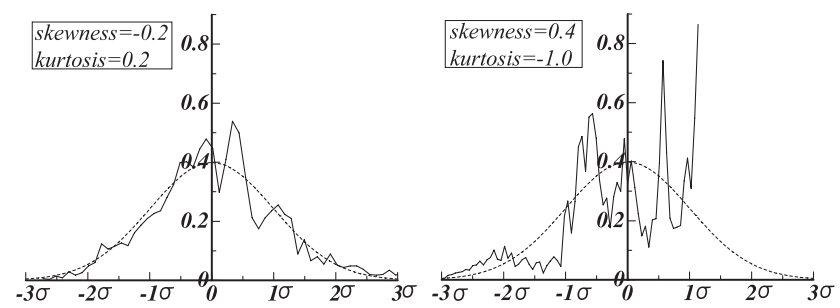

第6図 確率密度 第 10 図(1) 第 7 図 確率密度 第 13 図(2) 実線: ピーク $S t$ の確率密度 $(z=75 \mathrm{~mm})$, 破線 : 標準正規分布.

計算ができていると判断する.

5.2 キャビティありの場合 本研究の目的に沿うように, キャビティの位置を計算と実験それぞれの境界層再付着点に 設置した (第 2 図). 従って, 境界層再付着点のずれに合わ せ, 計算でのキャビティの位置は実験での位置より $s$ 方向に $17.3[\mathrm{~mm}]$ 下流に設置した（第 4 図 : 計算 $L 0=158[\mathrm{~mm}]$, 実験 $L 0=143[\mathrm{~mm}])$.

計算上の剝離泡が実験より大きく出たことから，実験の 境界層は乱流化しているとも推測できるが，実験に使用し た名古屋大学衝撃風洞（第 2 表）に設置された水平平板（長 さ300 $[\mathrm{mm}])$ 上の境界層はプレストン管にて総圧分布が測 定されており，テストセクション全域で層流であることが 確認されている13). また確認のために, 剝離泡を伴う流れ 場に適した一次方程式乱流モデル Spalart-Allmaras ${ }^{14)}$ 使用して計算も行ったが, 剝離泡が小さくなり境界層再付 着点が実験值から $s$ 方向に約 $19.6[\mathrm{~mm}]$ 上流側にずれ, 実 験值からのずれが層流の場合より大きくなった. 以上から, 本流れ場への乱流モデルの使用は不適当であると判断し, 境界層再付着点について計算上で実験值への合わせ込みを するのではなく, 実験と計算それぞれの境界層再付着点に キャビティを設置することにした.

キャビティありの結果は, 計算を第 11 図に, 実験を第 12 図に示す。キャビティ後縁壁が流れの障害物になり, 水平 板上の逆圧力勾配が大きくなるために実験と計算共にキャ ビティがない場合と比較して剝離泡が大きく成長している. 境界層再付着点はこの逆圧力勾配の影響により, キャビティ 内部に位置することはできず, キャビティ後縁壁のエッジ に位置している。

第 13 図にキャビテイがある場合の壁面熱流束の結果を 示す. 計算結果 $\langle S t\rangle$ は, 5.1 節のキャビティなしの場合 と同様にスパン方向断面平均值を流れ場が定常状態にな ってからの時間平均した統計量（第 4 表）である。第 13 


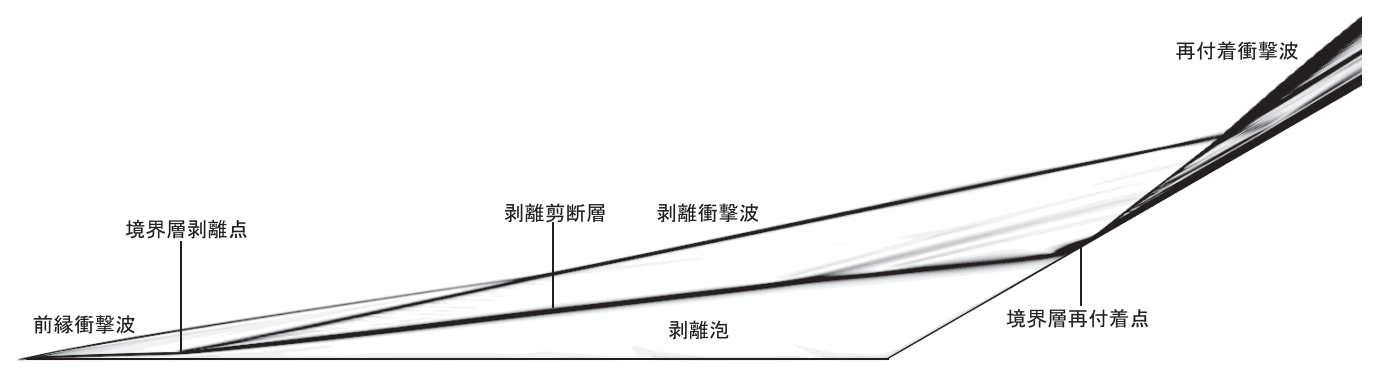

第 8 図計算：密度勾配（キャビティなし）

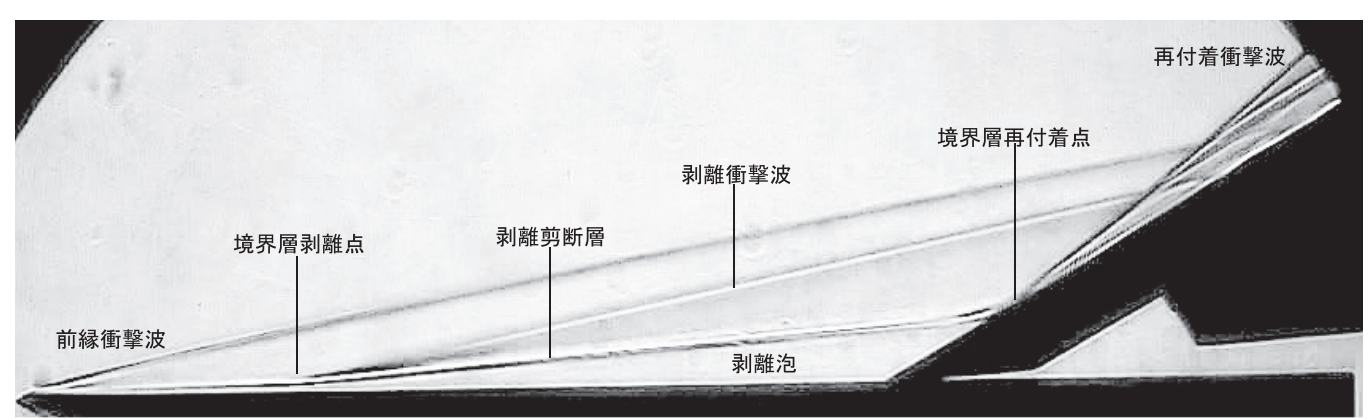

第 9 図 実験：シュリーレン写真（キャビティなし）

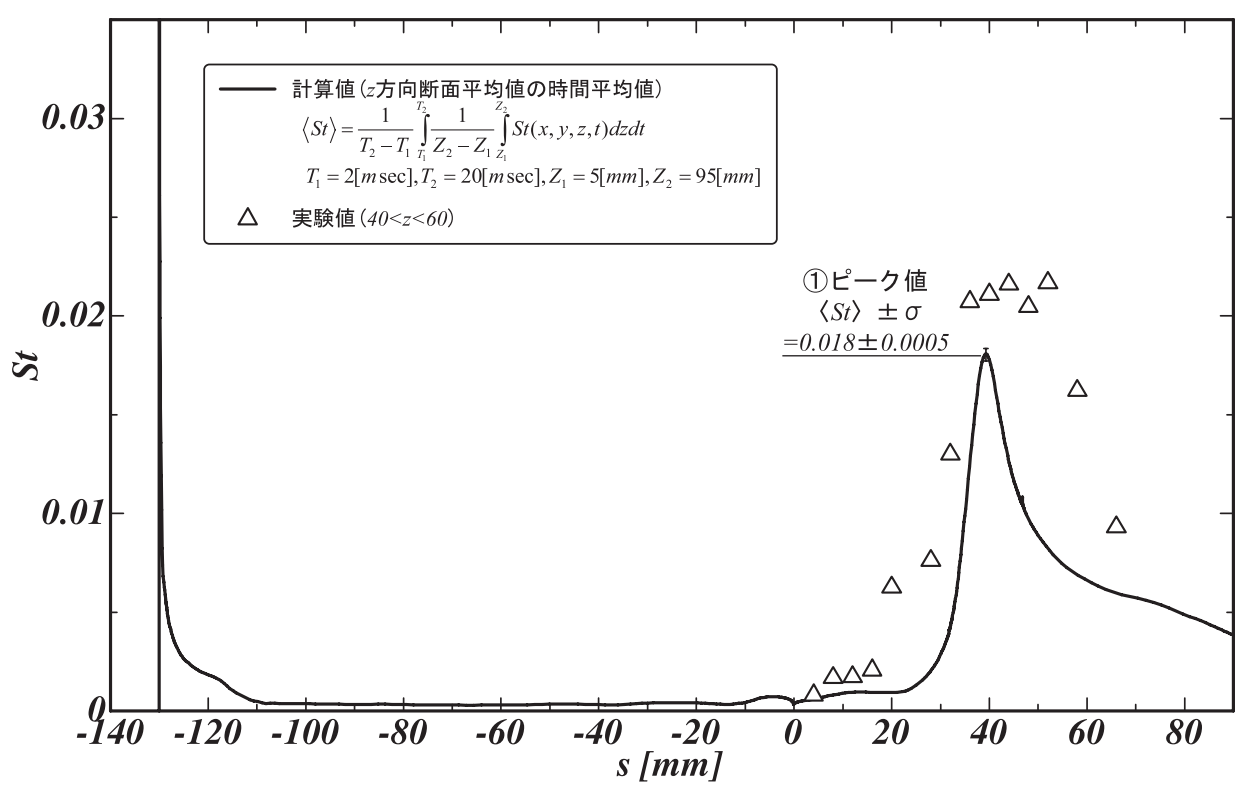

第 10 図 壁面熱流束（キャビティなし）

図中の座標系は，実験と計算でキャビティの位置が異なる ために，キャビティの後縁壁を基準点 $s_{0}$ とした $\Delta s=$ $s-s_{0}$ としている. 従って, キャビティ後縁壁は $\Delta s=$ $0 \sim-1$ に位置し, キャビティ底壁は $\Delta s=-1 \sim-11$ に 位置する。キャビティの効果により, キャビティ底壁では, $\langle S t\rangle \pm \sigma=0.1 \pm 0.01\left(150.7 \pm 18.7\left[\mathrm{~W} / \mathrm{cm}^{2}\right]\right)$ に, キャ ビティ後縁壁エッジ部 $\Delta s \approx 0$ (境界層再付着点付近) は, $\langle S t\rangle \pm \sigma=0.048 \pm 0.006\left(75.7 \pm 9.4\left[\mathrm{~W} / \mathrm{cm}^{2}\right]\right)$ となり，そ れぞれキャビティがない場合のピーク值の 5.3 倍と 2.7 倍 になった。最も壁面熱流束が上昇したのは, キャビティ後 縁壁で, $\langle S t\rangle \pm \sigma=0.177 \pm 0.03\left(280.1 \pm 47.9\left[\mathrm{~W} / \mathrm{cm}^{2}\right]\right)$
となり，キャビテイがない場合のピーク值の 9.8 倍になっ た.また，キャビティ四隅の頂点の格子点は特異点である ので，第 13 図の計算結果からは削除してある. 実験值は熱 電対の空間分解能の制限によりピーク值の確認はできない が，ピーク值以外については計算結果とほぼ一致している.

第 14 図において，壁面熱流束が増加するメカニズムにつ いて説明する。キャビティ後縁壁は時空間を平均的に見る と, (a)にあるように剝離剪断層が後縁壁に衝突する流れ場 となっている。さらにその剥離剪断層は高速流れであるた めに剪断による粘性散逸により約 $700[\mathrm{~K}]\left(T / T_{\infty} \fallingdotseq 11\right)$ ま で加熱されている。キャビティの後縁壁では, この高温の 


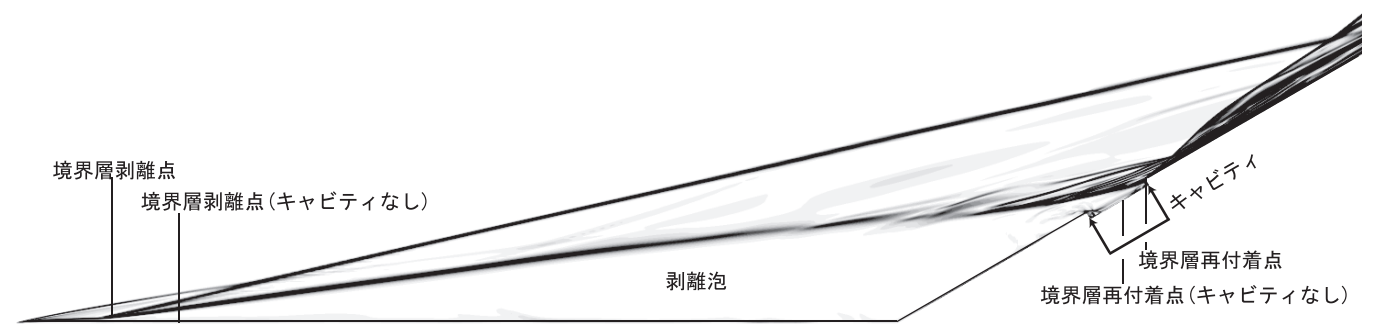

第11図 計算：密度勾配（キャビティあり）

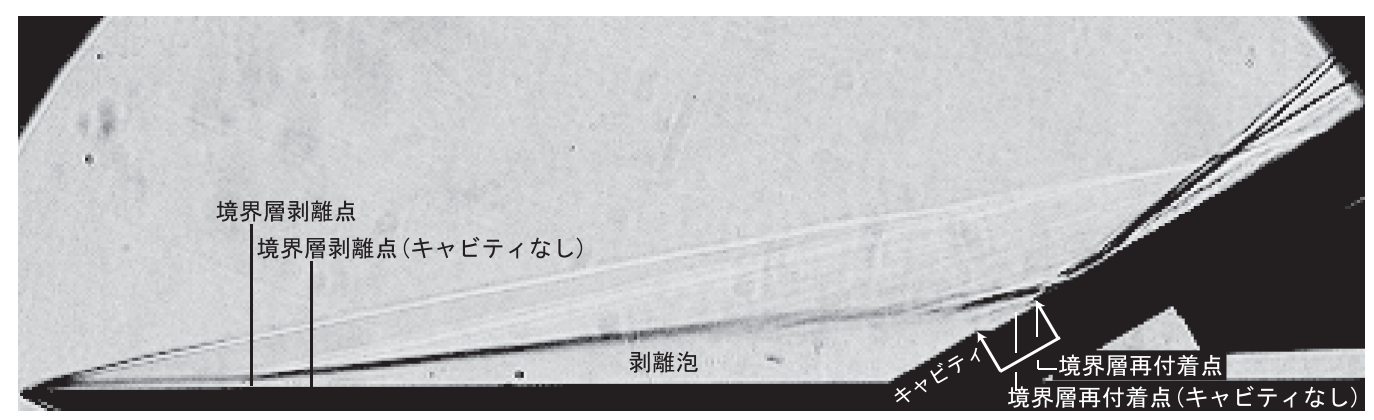

第 12 図＼cjkstart実験：シュリーレン写真（キャビティあり）

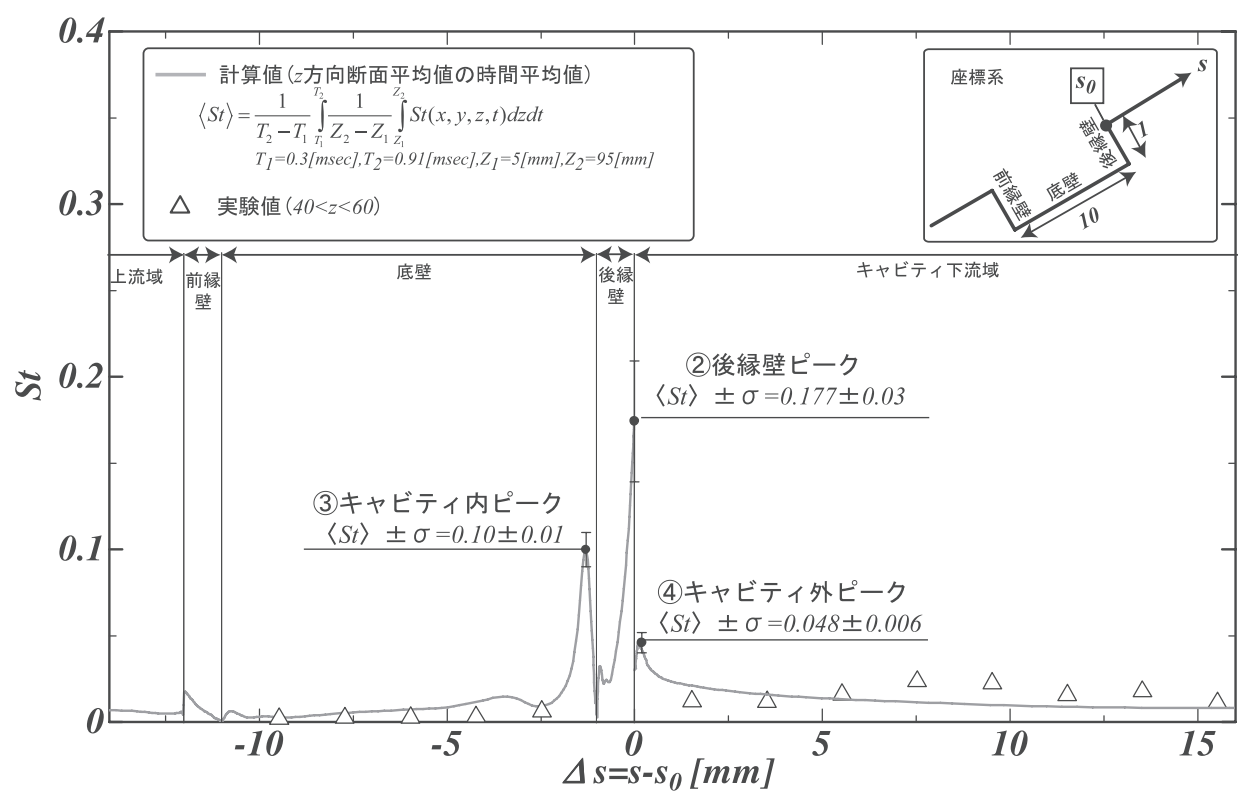

第13図＼cjkstart壁面熱流束（キャビティあり）

高速流れが衝突し澱点 $(S 1)$ が形成される。キャビティ底面 にはこの澱点からの噴流が衝突し, 同様に澱点 $(S 2)$ が形 成される。これらの澱点では高温となるために, 壁面熱流 束がキャビティがない場合のピーク值の $S 1$ では 9.8 倍に, $S 2$ では 5.3 倍になっている. また, キャビティ後縁壁(2)の $S t_{2}$ とキャビティ底部(3の $S t_{3}$ の間には, 断面平均相関係 数 $\bar{R}_{23}=0.85$ (式 (10)）であり, 澱点 $S 1$ と $S 2$ が一連 の現象の中で発生していることが分かる、第 15 図には, 流 れ場が十分落ち着いた範囲内の任意の時刻でのキャビティ 後縁壁付近の壁面熱流束の瞬時值 $(t=0.779[\mathrm{msec}])$ を示 す。この図からも, 後縁壁の熱流束が大きい $z$ 断面では,
キャビティ内の熱流束も大きく $S 1$ と $S 2$ が一連の現象で あることが確認できる.

$$
\bar{R}_{23}=\frac{1}{z_{2}-z_{1}} \int_{z_{1}}^{z_{2}} \frac{\Sigma\left(S t_{2}-\overline{S t_{2}}\right)\left(S t_{3}-\overline{S t_{3}}\right)}{\sqrt{\Sigma\left(S t_{2}-\overline{S t_{2}}\right)^{2}} \sqrt{\Sigma\left(S t_{3}-\overline{S t_{3}}\right)^{2}}} \mathrm{~d} z
$$

また，剝離剪断層のキャビティ後縁壁への衝突は間欠的 で，衝突夕イミングとそうでない夕イミングが存在してい た. 第 7 図に $z=75[\mathrm{~mm}]$ 断面のキャビティ後縁壁のピー ク值(2)の確率密度の分布を示す。この分布は正弦波の確率 密度と同じように両サイドにピークがあり, 中心のピーク 


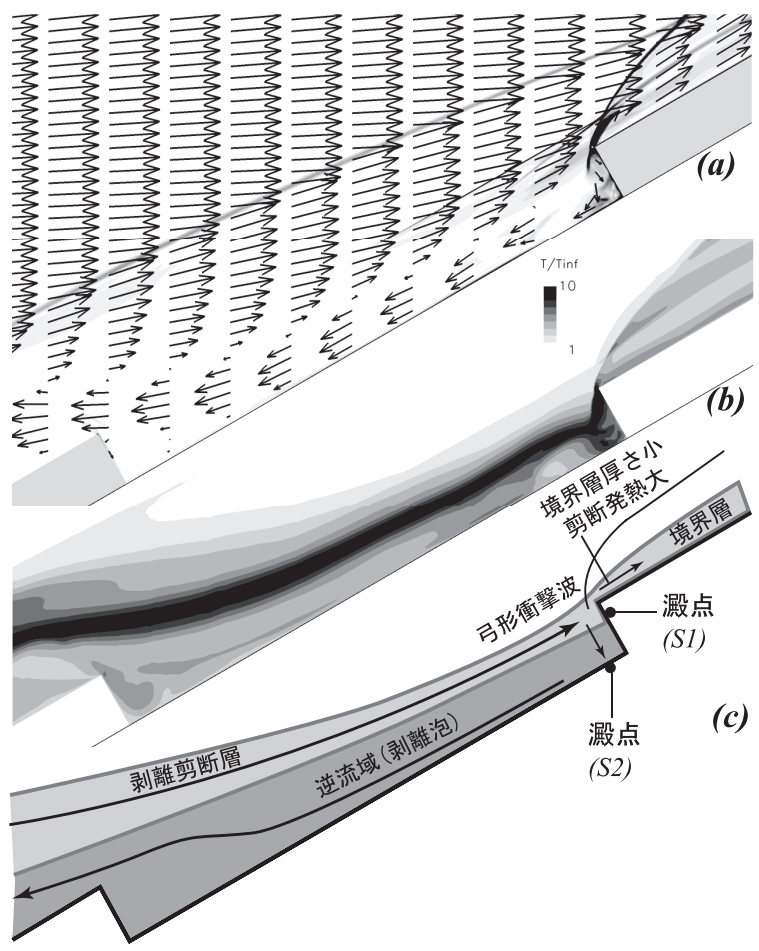

第 14 図 キャビティの流れ場

(a) 流速ベクトルと密度の空間微分の分布, (b) 静温分布 $T / T_{\infty}, \quad(\mathrm{c})$ 流れ場の模式図.

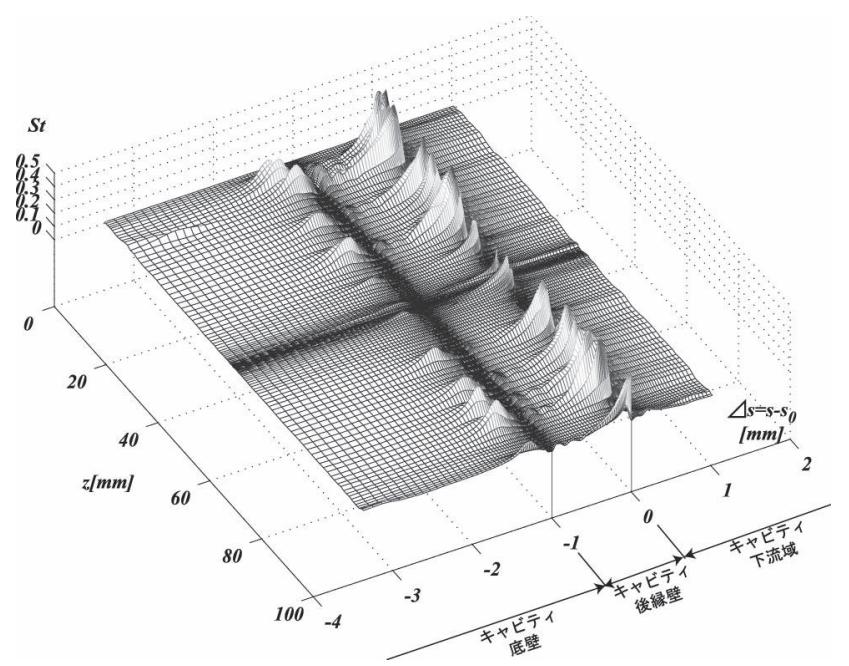

第 15 図 キャビティ後縁壁付近の熱流束の瞬時值 $(t=0.779[\mathrm{msec}])$

が小さく, 尖度が負になっていることからも, 間欠的な現 象であることが理解できる. $z=75[\mathrm{~mm}]$ 以外の断面も夕 イミングはそれぞれ異なるが間欠性がみられた。第 15 図 からも同様に, 熱流束が大きい $z$ 断面と小さい $z$ 断面が あり，熱流束の間欠性がみられる。

キャビティ後縁壁エッジ付近は, 第 10 図の水平板前縁の ピークと同様で, 境界層の成長初期段階であり, 非常に薄 い境界層厚さとなっており, 剪断による粘性散逸により大 量の発熱が発生するために壁面熱流束がキャビティがない 場合のピーク值の 2.7 倍になったと考える.
6. 結 論

極超音速流中 $\left(M_{\infty}=8.1\right)$ に設置された水平板長さ $130[\mathrm{~mm}]$ で斜板角度 $30[\mathrm{deg}]$ からなる圧縮コーナ（レイ ノルズ数 $R e \equiv \rho_{\infty} M_{\infty} c_{\infty} L / \mu_{\infty}=8.0 \times 10^{5}$, 代表長さ $L$ : 水平板長さ $130[\mathrm{~mm}])$ の境界層再付着点を中心にスパン 方向に断面形状が変化しない矩形キャビティ（幅 $10[\mathrm{~mm}]$, 高さ $1[\mathrm{~mm}]$ ）を設置した流れ場の 3 次元圧縮性ナビエ・ス トークスによる計算及び実験を行ったところ以下の知見を 得た。

・計算及び実験結果より，キャビティの後縁壁による逆圧 力勾配の影響のため, キャビティなしの場合と比較して 剝離泡が大型化した。

・計算結果より, キャビティ後縁壁に約 $700[\mathrm{~K}]$ まで加熱さ れた高温の剪断層が衝突する流れ場となり, 澱点が形成 され, キャビティ後縁壁では, キャビティなしのピーク 值の約 10 倍の壁面熱流束となることが明らかになった. 従って, 境界層再付着点位置にキャビティがあると, 本 件の条件下で生じた現象のようにキャビティ後縁部付近 は熱的に最も厳しい領域となる場合があると判断する。

\section{参 考 文 献}

1) Columbia Accident Investigation Board Report Volume 1, National Aeronautics and Space Administration and the Government Printing Office, 2003, pp. 49-84, http://caib.nasa.gov/news/report/default.html

2) Everhart, J. L.: Supersonic/Hypersonic Laminar Heating Correlations for Rectangular and Impact-Induced Open and Closed Cavities, AIAA Paper 2008-1283, 2008.

3) Murray, R. C. and Elliott, G. S.: Characteristics of the Compressible Shear Layer over a Cavity, AIAA J., 39 (2001), pp. 846-856.

4) Lin, J. C. and Rockwell, D.: Organized Oscillations of Initially Turbulent Flow Past a Cavity, LM-00k80, 2000.

5) Holden, M. S.: Experimental Studies of Separated Flow at Hypersonic Speeds. Part II: Two-Dimensional Wedge Separated Flow Studies, AIAA J., 4 (1966), pp. 790-799.

6) Hilsenralh, J., Beckett, C. W., Benedict, W. S., Fano, L., Hoge, H. J., Masi, J. F., Nuttoll, R. L., Touloukian, Y. S. and Woolley, H. W.: Tables of Thermal Properties of Gases, National Bureau of Standards Circular 564, 1955.

7) Shima, E. and Jounouchi, T.: Role of CFD in Aeronautical Engineering (No. 14), AUSM Type Upwind Schemes, 第 14 回航空機計算空気力学シンポジウム論文集，NAL SP-34, 1997.

8) Yoon, S. and Jameson, A.: An LU-SSOR Scheme for the Euler and Navier-Stokes Equations, AIAA Paper 87-0600, 1987.

9) Obayashi, S. and Kuwahara, K.: An Approximate LU Factorization Method for the Compressible Navier-Stokes Equations. J. Comput. Phys., 63 (1986), pp. 157-167.

10）倉谷健治, 土屋荘次: 衝撃波の化学物理, 裳華房, 1968, 第 1 章, pp. $11-26$.

11）金子宗嗣, 中村佳朗：衝撃風洞貯気槽温度に対する衝撃波/境界 層干涉の影響, 日本航空宇宙学会論文集, 53 (2005), pp. 36-41.

12) Cook, W. J. and Felderman, E. J.: Reduction of Data from Thin Film Heat Transfer Gauges, A Concise Numerical Technique, AIAA J., 4 (1966), pp. 561-562.

13）鈴木由克：基本形状周りの極超音速流れの解析, 修士論文, 名古 屋大学大学院工学研究科航空工学専攻第一講座, 1990 .

14) Spalart, P. R. and Allmaras, S. R.: A One-Equation Turbulence Model for Aerodynamic Flows, AIAA Paper 1992-0439, 1992. 